\title{
Karakteristik Edible Film Aloe vera dengan Emulsi Extra Virgin Olive Oil dan Kitosan
}

\author{
Properties of Aloe vera Edible Film with Extra Virgin Olive Oil and Chitosan Emulsion
}

\author{
M. Miranda, Yoga Pratama*, Antonius Hintono
}

Program Studi Teknologi Pangan, Fakultas Peternakan dan Pertanian, Universitas Diponegoro,
Kampus drh. R. Soejono Koesoemowardoyo Tembalang, Semarang 50275, Indonesia
*Email: yogapratama@live.undip.ac.id

Tanggal submisi: 4 Mei 2018; Tanggal penerimaan: 16 November 2018

\begin{abstract}
ABSTRAK
Edible film merupakan kemasan ramah lingkungan yang potensial digunakan dalam industri pangan. Penelitian ini bertujuan untuk mengetahui karakteristik fisik, kimia dan mekanik edible film Aloe vera dengan emulsi extra virgin olive oil dan kitosan. Percobaan menggunakan Rancangan Acak Lengkap (RAL) dengan lima perlakuan dan empat ulangan. Perlakuan yang digunakan yaitu perbandingan komposisi gel Aloe vera dengan emulsi extra virgin olive oil (EVOO) dan kitosan yang terdiri dari T1 (40:60 (v/v) ), T2 (45:55), T3 (50:50), T4 (55:45) dan T5 (60:40). Metode pembuatan edible film diawali dengan pembuatan gel Aloe vera dan emulsi EVOO 1\% (v/v) dalam kitosan $1 \%(b / v)$, pencampuran bahan sesuai perlakuan, pencetakan dan pengeringan. Hasil penelitian menunjukkan ketebalan film berkisar 0,067-0,073 mm, solubilitas 48,70-65,73\%, permeabilitas uap air $1,39 \times 10^{-5}-1,77 \times 10^{-5}$ $\mathrm{gmmHg}^{-1} \mathrm{~m}^{-1} \mathrm{~h}^{-1}$, aktivitas antioksidan 3,31-6,56\%, elongasi 6,78-14,72\% dan tensile strength 0,29-0,68 MPa. Komposisi edible film Aloe vera dan emulsi EVOO-kitosan terhadap ketebalan, solubilitas, aktivitas antioksidan, elongasi dan tensile strength berpengaruh nyata $(p \leq 0,05)$ namun tidak berpengaruh terhadap permeabilitas uap air film $(p \geq 0,05)$.
\end{abstract}

Kata kunci: Gel Aloe vera; kitosan; edible film;extra virgin olive oil

\begin{abstract}
Edible film is a potential biodegradable packaging in the food industry. This research is aimed to determine the physical, chemical and mechanical properties of Aloe vera with extra virgin olive oil and chitosan emulsion edible film. Complete Randomized Design was used with five treatments and four repetitions. The treatments were composition ratio between Aloe vera gel and extra virgin olive oil (EVOO) - chitosan emulsion that consists of T1 (40:60), T2 (45:55), T3 (50:50), T4 (55:45) and T5 (60:40). The method used in this study included making Aloe vera gel and an emulsion of EVOO $1 \%(\mathrm{v} / \mathrm{v})$ in chitosan $1 \%(\mathrm{~b} / \mathrm{v})$, homogenizing the materials, casting and drying. The results showed that range of film thickness, solubility, water vapor permeability, antioxidant activity, extension and tensile strength were $0.067-0.073 \mathrm{~mm}$, solubility $48.70-65.73 \%, 1.39 \times 10^{-5}-1.77 \times 10^{-5} \mathrm{~g} \mathrm{~mm} \mathrm{Hg}^{-1} \mathrm{~m}^{-1} \mathrm{~h}^{-1}$, $3.31-6.56 \%, 6.78-14.72 \%$ and $0.29-0.68 \mathrm{MPa}$. The edible film composition showed significant difference ( $p \leq$ $0,05)$ for thickness, solubility, antioxidant activity, extension and tensile strength film, however, the water vapor permeability was not significantly different $(p \geq 0,05)$.
\end{abstract}

Key words: Aloe Vera gel; chitosan; edible film; extra virgin olive oil 


\section{PENDAHULUAN}

Produksi makanan yang kian meningkat dan beragam jenis menyebabkan semakin tinggi pula kebutuhan produsen dalam memenuhi kriteria kemasan. Kesadaran konsumen terkait isu lingkungan dan sampah mendorong munculnya upaya penggunaan kemasan ramah lingkungan menggantikan kemasan dari bahan tak terbarukan (Talegaonkar dkk., 2017). Edible film merupakan salah satu alternatif kemasan ramah lingkungan (biodegradable) yang berupa lapisan tipis dari bahan yang dapat dimakan (Bhattacharjee dan Dhua, 2017). Hal ini menyebabkan penelitian terkait edible film dengan pengembangan berbagai bahan biopolimer semakin diminati.

Aloe vera adalah tanaman famili Liliaceace yang banyak tumbuh di daerah tropis dan subtropis karena sifatnya yang tahan kering. Gel Aloe vera merupakan lapisan bening yang diperoleh dari sel parenkim daun Aloe vera segar. Kandungan bioaktif dalam gel Aloe vera antara lain antraquinon (aloin, barbaloin, emodin), sakarida (selulosa, manosa, glukomanan), vitamin (B1, B2, B6, C) dan enzim (amilase, katalase, lipase) (OrtegaToro dkk., 2017). Ekstrak dari Aloe vera ini secara alami mengandung antioksidan dan antimikroba yang mampu melawan bakteri patogen sehingga berpotensi sebagai bahan dasar edible film (Chauhan dkk., 2016).

Namun total padatan dalam gel Aloe vera yang rendah dapat menyebabkan film yang dihasilkan terlalu tipis dan rentan putus. Penambahan komponen minyak sebagai lemak dapat meningkatkan total padatan dan memiliki peran tambahan meningkatkan sifat barrier. Penggunaan minyak zaitun (olive oil) dalam edible film mampu meningkatkan karakteristik mekanik film antara lain Young Modulus, tensile strength dan elongasi (Pereda dkk., 2012). Daya resistensi film terhadap air juga meningkat seiring bertambahnya komponen minyak zaitun yang bersifat hidrofobik (Ma dkk., 2012).

Emulsifier diperlukan dalam proses pencampuran komponen minyak dan gel Aloe vera. Kitosan selain berperan sebagai polisakarida juga dapat dimanfaatkan dalam menstabilkan minyak pada pembentukan film. Kitosan memiliki banyak gugus positif $\mathrm{NH}^{+3}$ ketika dilarutkan dalam larutan asam, sehingga mampu mengikat atau menyatu dengan komponen minyak yang bermuatan negatif (Pereda dkk., 2012). Molekul kitosan juga terdiri dari komponen hidrofilik dan hidrofobik yang baik membentuk emulsi dan ikatan penstabil antara campuran hidrokoloid dan minyak. Penambahan kitosan mampu membentuk film dengan sifat mekanik yang baik dan meningkatkan moisture barrier (Chillo dkk., 2008).
Penelitian ini dilakukan dengan tujuan untuk mengetahui pengaruh perbandingan komposisi gel Aloe vera dengan emulsi extra virgin olive oil (EVOO) dan kitosan terhadap karakteristik edible film yang meliputi sifat fisik, kimia dan mekanik. Adapun manfaat dari penelitian ini yaitu dapat memberikan informasi mengenai karakteristik edible film Aloe vera dengan emulsi extra virgin olive oil dan kitosan yang optimal sebagai dasar pengaplikasian dan pengembangan penelitian selanjutnya.

\section{METODE PENELITIAN}

\section{Bahan}

Bahan yang digunakan terdiri dari Aloe vera segar dengan panjang sekitar $30-45 \mathrm{~cm}$, extra virgin olive oil (EVOO) (Filippo Berio, Semarang), kitosan (derajat deasetilasi 92\%, dibeli dari Che-Mix Yogyakarta), aquades, asam asetat (Emsure, Jerman) 0,5\% (v/v), gliserol (Indrasari, Semarang), metanol, silica gel dan wax.

\section{Metode}

\section{Preparasi Gel Aloe vera}

Pembuatan gel Aloe vera dilakukan menurut petunjuk Soltanizadeh dan Mousavinejad (2015). Aloe vera segar dicuci dan dipisahkan dari bagian sisi atas dan bawah daun. Aloe vera kemudian dipotong menjadi beberapa bagian dan dicuci ulang dengan air bersih. Setelah itu potongan Aloe vera dihaluskan dan hasilnya disaring dengan saringan berdiameter $1 \mathrm{~mm}^{2}$. Filtrat yang diperoleh dari proses penyaringan merupakan gel Aloe vera yang siap digunakan.

\section{Preparasi Emulsi EVOO dan Kitosan}

Pembuatan emulsi EVOO dan kitosan mengikuti metode yang dilakukan Chillo dkk. (2008) yang dimodifikasi. Larutan kitosan dibuat terlebih dahulu dengan cara melarutkan kitosan $1 \%(\mathrm{~b} / \mathrm{v})$ dalam asam asetat $0.5 \%(\mathrm{v} / \mathrm{v})$. Proses pelarutan dilakukan dengan cara diaduk menggunakan magnetic stirrer (Thermolyne, Cimarec SP131325, Amerika) selama \pm 90 menit. Emulsi EVOO dan kitosan kemudian dibuat dengan cara homogenisasi EVOO sebanyak $1 \%(\mathrm{v} / \mathrm{v})$ dalam larutan kitosan menggunakan homogenizer (Ultra Turrax, IKA T25, Jerman) dengan kecepatan 15000 rpm selama 10 menit.

\section{Proses Pembuatan Edible Film}

Pembuatan edible film dilakukan seperti yang dikerjakan Diaz dkk. (2017) dengan modifikasi yaitu gel 
Aloe vera dan emulsi EVOO-kitosan dicampurkan terlebih dahulu sesuai perlakuan.Perlakuan perbandingan komposisi gel Aloe vera dan emulsi EVOO-kitosan terdiri dari T1 (40:60 (v/v)), T2 (45:55), T3 (50:50), T4 (55:45) dan T5 (60:40). Gliserol ditambahkan sebanyak $0,3 \%$ (v/v) ke dalam masing-masing campuran larutan lalu dihomogenisasi dengan homogenizer berkecepatan $12000 \mathrm{rpm}$ selama 5 menit. Larutan film kemudian dituang ke dalam teflon berukuran $18 \mathrm{~cm}$ dan dikeringkan dalam oven pengering pada suhu $37^{\circ} \mathrm{C}$ selama $24 \pm 2$ jam. Penggunaan teflon yang bersifat anti lengket akan mempermudah proses pencetakan film ketika dilepaskan pasca pengeringan. Lembar film yang telah kering diambil dan disimpan terlebih dahulu selama 48 jam dalam desikator sebelum dianalisis.

\section{Pengukuran Ketebalan}

Pengukuran ketebalan dilakukan menurut petunjuk Gunes dan Tihminlioglu (2017) yaitu dengan menggunakan mikrometer (Herma, Jerman) dengan sensitivitas $0,001 \mathrm{~mm}$. Tiap sampel film diukur pada lima titik berbeda yang kemudian dirata-rata sebagai nilai akhir.

\section{Penentuan Solubilitas}

Solubilitas film diukur mengikuti metode yang dilakukan Indrarti dan Indriyati (2016) yang dimodifikasi. Lembar sampel film dipotong $2 \mathrm{~cm} 2 \mathrm{~cm}$ dan ditimbang terlebih dahulu $\left(B_{1}\right)$. Film direndam dalam $50 \mathrm{ml}$ aquades dan diaduk selama 30 menit. Sisa bagian film yang telah direndam diambil dengan pinset lalu dikeringkan pada suhu $110{ }^{\circ} \mathrm{C}$ selama dua jam dan ditimbang sebagai berat kering $\left(\mathrm{BK}_{1}\right)$. Persentase solubilitas dihitung seperti pada Persamaan 1.

$$
\text { Solubilitas }=\frac{B_{1}-B_{1}}{B_{1}} \times 100
$$

\section{Penentuan Permeabilitas Uap Air}

Permeabilitas uap air atau WVTR (Water Vapor Transfer Rate) diukur mengikuti metode yang dilakukan oleh Siripatrawan dan Harte (2010) yang dimodifikasi. Gelas kaca yang berisi silica gel ditutup menggunakan sampel film dengan bantuan wax dan karet gelang. Sebelum dilakukan penyimpanan, gelas ditimbang dan luas area film pada bibir gelas dihitung. Penyimpanan dilakukan selama 5 jam dalam cabinet dryer (Krisbow, AD-160, Indonesia) dengan suhu $24 \pm 1{ }^{\circ} \mathrm{C}$ dan kelembapan $54 \pm 2 \%$. Gelas kemudian ditimbang setiap 30 menit. Setelah penyimpanan, nilai water vapor transfer rate dihitung seperti pada Persamaan 2:

$$
\text { WVTR }=\frac{\Delta \mathrm{W}}{\mathrm{A} \Delta \mathrm{t}}
$$

Keterangan:

WVTR $=$ Water vapor transfer rate $\left(\mathrm{g} \mathrm{m}^{-2} \mathrm{~h}^{-1}\right)$

= Berat uap air yang melewati film (g)

A $=$ Luas permukaan film $\left(\mathrm{m}^{2}\right)$

= Waktu simpan (h)

Permeabilitas uap air kemudian dihitung setelah nilai WVTR (Persamaan 3-4).

$$
\begin{aligned}
& P=\text { WVTR } \times \frac{x}{\Delta p} \\
& \Delta p=S \times R_{1}-R_{2}
\end{aligned}
$$

Keterangan:

$\mathrm{P}=$ Permeabilitas uap air $\left(\mathrm{g} \mathrm{mmHg} \mathrm{m}^{-1} \mathrm{~m}^{-1}\right)$

$\mathrm{x}=$ Ketebalan film $(\mathrm{m})$

$=$ Perbedaan tekanan uap air bagian dalam dan luar permukaan film $(\mathrm{mmHg})$

$\mathrm{S}=$ Tekanan uap air jenuh pada suhu pengujian $(\mathrm{mmHg})$

$\mathrm{R}_{1}=$ Relative Humidity $(\mathrm{RH})$ ruangan pengujian $(\mathrm{mmHg})$

$\mathrm{R}_{2}=$ Relative Humidity $(\mathrm{RH})$ dalam kemasan (diasumsikan $=0$ )

\section{Penentuan Aktivitas Antioksidan}

Antioksidan diukur mengikuti modifikasi metode yang dilakukan oleh Jouki dkk. (2013) yaitu setiap sampel film ditimbang sebanyak 500 mg kemudian dilarutkan dalam $5 \mathrm{~mL}$ metanol. Larutan didiamkan selama dua jam kemudian disaring dengan kertas saring. Filtrat larutan film diambil sebanyak $0,1 \mathrm{~mL}$ dan ditambahkan $3,9 \mathrm{ml}$ larutan DPPH lalu diinkubasi pada suhu ruang selama 30 menit. Absorbansi sampel diukur dengan menggunakan spektrofotometer uv-vis (Shimadzu, UV-1280, Jepang) pada panjang gelombang $517 \mathrm{~nm}$. Pengujian aktivitas antioksidan dilakukan secara triplicate. Perhitungan persentase aktivitas antioksidan (Persamaan 5).

$$
\text { Aktivitas Antioksidan }=\left(\frac{\text { Ablangko }-A_{\text {sammel }}}{A_{\text {blangko }}}\right) \times 100
$$

Keterangan:

$\mathrm{A}_{\text {blangko }}=$ Absorbansi larutan blangko

$\mathrm{A}_{\text {sampel }}=$ Absorbansi larutan sampel

\section{Pengukuran Elongasi dan Tensile Strength (TS)}

Pengukuran elongasi dan tensile strength (TS) dilakukan menurut Thakur dkk. (2017) yaitu dengan menggunakan texture analyzer (Ametek, TA1, Amerika) berdasarkan modifikasi metode ASTM D 882-91. Sampel film dipotong berukuran $151 \mathrm{~cm}$ lalu diletakkan diantara ujung penarik (jarak gap $7 \mathrm{~cm}$ ) dengan kecepatan 8,33 $\mathrm{mm} / \mathrm{s}$ dan preload $10 \mathrm{gf}$. Nilai elongasi ditulis dalam satuan persen (\%) sedangkan TS dalam satuan MPa.

\section{Analisis Statistik}

Data dianalisis dengan One-way analysis of variance (Anova) dan Duncan's multiple range test pada taraf kepercayaan $95 \%(p \leq 0.05)$ dengan menggunakan 
aplikasi SPSS 23.0 (Orsuwan dan Sothornvit, 2017). Parameter aktivitas antioksidan disajikan menggunakan analisis deskriptif.

\section{HASIL DAN PEMBAHASAN}

\section{Karakteristik Fisik Edible Film}

Ketebalan edible filmyang dihasilkan berkisar 0,067$0,073 \mathrm{~mm}$ seperti dapat dilihat pada Gambar 1 . Nilai ini lebih tinggi dibandingkan ketebalan film berbahan dasar gel Aloe vera dan tepung tapioka yang berkisar 0,0640,067mm (Ortega-Toro dkk., 2017). Terdapat pengaruh signifikan $(p \leq 0,05)$ antara komposisi gel Aloe vera dengan emulsi EVOO dan kitosan. Uji lanjut Duncan menunjukkan perbedaan nyata antara perlakuan T3 terhadap perlakuan T1 dan T5. Peningkatan ketebalan film dapat dilihat dari 0,067 $\pm 0,002 \mathrm{~mm}$ menjadi 0,073 $\pm 0,003 \mathrm{~mm}$ pada perlakuan T3. Penurunan kemudian terjadi hingga 0,067 $\pm 0,003 \mathrm{~mm}$ pada perlakuan $\mathrm{T} 5$. Ikatan yang terbentuk antara emulsi kitosan dan gel Aloe vera memiliki peran dalam ketebalan film. Komponen fenolik dari bahan dapat berinteraksi membentuk ikatan hidrogen atau kovalen dengan komponen aktif dari kitosan sehingga meningkatkan ikatan intermolekular pada polimer film (Siripatrawan dan Harte, 2010). Kelompok amino dan hidroksil dari kitosan berperan utama sebagai pembentuk ikatan intermolekular film seperti ikatan $\Pi$, hidrogen, hidrofobik maupun ionik. Menurut Shabrina dkk. (2017) penggunaan minyak juga meningkatkan ketebalan film akibat jumlah total padatan yang bertambah. Beberapa faktor yang mempengaruhi ketebalan film antara lain banyak total padatan dan volume larutan film serta luas cetakan (Santoso dkk., 2014).

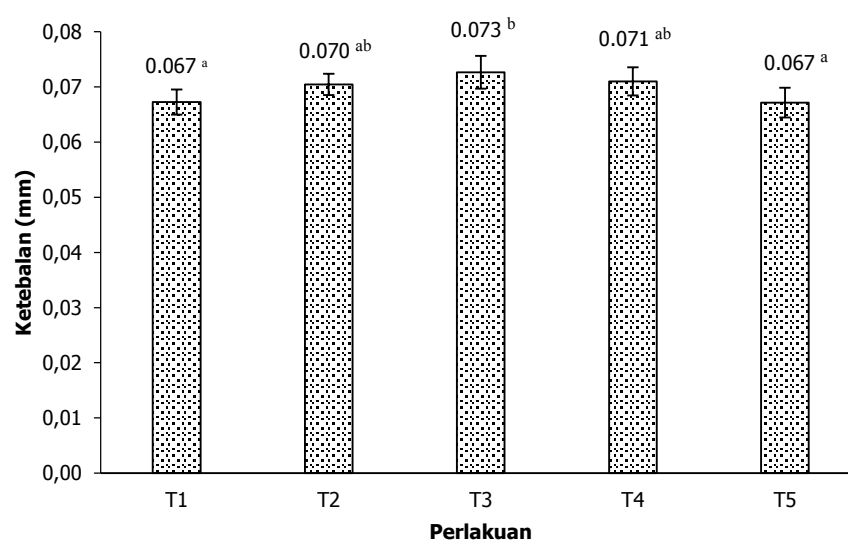

Gambar 1.Pengaruh Komposisi AV dan Emulsi EVOO-Kitosan Terhadap Ketebalan

Keterangan: superskrip yang berbeda menunjukkan adanya perbedaan yang signifikan $(p \leq 0,05)$
Berdasarkan hasil yang diperoleh pada Gambar 2, semakin bertambahnya komposisi gel Aloe vera maka semakin bertambah pula daya solubilitas edible film. Penambahan gel Aloe vera yang bersifat hidrofilik akan meningkatkan jumlah gugus hidroksil bebas untuk menyerap lebih banyak air (Saibuatong dan Phisalaphong, 2010). Emulsi EVOO-kitosan yang mengandung minyak memiliki sifat hidrofobik yang menurunkan nilai solubilitas. Hal ini menunjukkan adanya perbedaan signifikan ( $p \leq 0,05)$ antar perlakuan. Uji lanjut Duncan menunjukkan perbedaan nyata antara perlakuan T1, T2 dan T5. Solubilitas tertinggi diperoleh pada perlakuan T5 yaitu $65,73 \pm 2,32 \%$ sedangkan perlakuan T1 memiliki solubilitas terendah yaitu 48,70 $\pm 4,55 \%$. Pada perlakuan komposisi gel Aloe vera $50 \%$ nilai solubilitas yang diperoleh yaitu $61,51 \pm 3,90 \%$ lebih tinggi dibandingkan penelitian Khosgozaran-Abras dkk. (2012) yaitu 59,99 $\pm 4,40 \%$. Edible film dengan solubilitas air yang tinggi dapat diaplikasikan sebagai

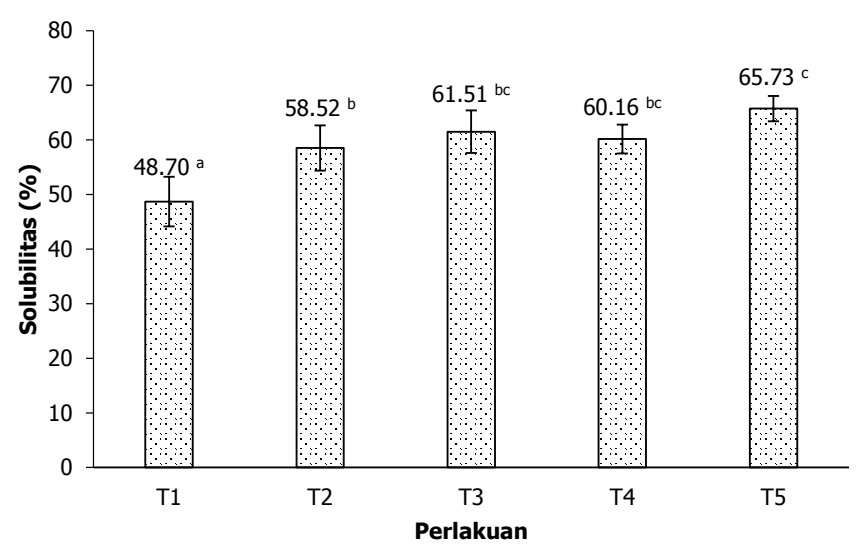

Gambar 2. Pengaruh komposisi AV dan emulsi EVOO-kitosan terhadap solubilitas

Keterangan: superskrip yang berbeda menunjukkan adanya perbedaan yang signifikan $(p \leq 0,05)$

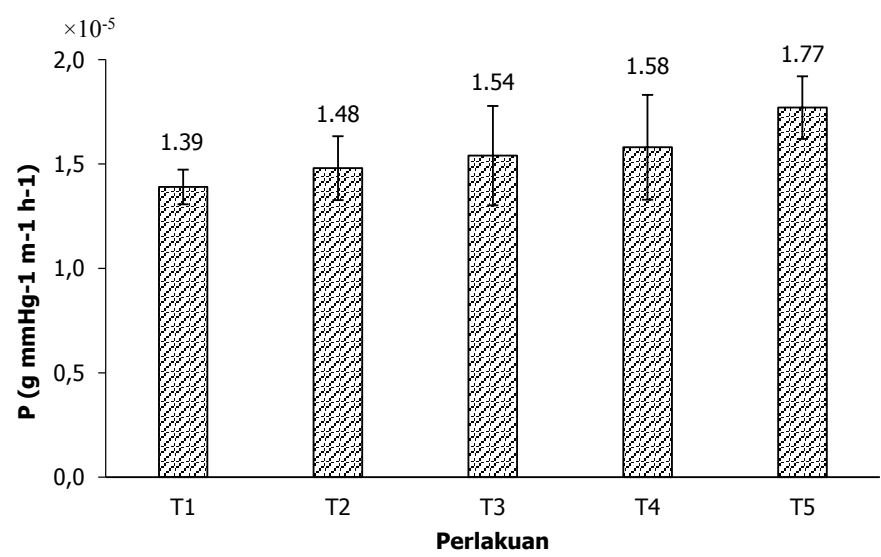

Gambar 3. Pengaruh komposisi AV dan emulsi EVOO-kitosan terhadap permeabilitas uap air 
pembungkus permen karena sifatnya mudah larut dan meleleh dalam mulut (Gutierrez dan Alvarez, 2016).

Pada Gambar 3 dapat diketahui permeabilitas uap air edible film dari kelima varian komposisi tidak memiliki perbedaan signifikan $(p \geq 0,05)$. Kisaran permeabilitas uap air yang diperoleh yaitu $1,39 \times 10^{-5}-1,77 \times 10^{-}$ ${ }^{5} \mathrm{~g} \mathrm{mmHg}^{-1} \mathrm{~m}^{-1} \mathrm{~h}^{-1}$. Jumlah ini lebih kecil dibandingkan permeabilitas film kitosan dan nanopartikel dari penelitian Casariego dkk (2009), yang bernilai sekitar 8,4 $\times 10^{-4}-1,41 \times 10^{-3} \mathrm{~g} \mathrm{mmHg}^{-1} \mathrm{~m}^{-1} \mathrm{~h}^{-1}$. Namun lebih besar dibandingkan permeabilitas film berbahan dasar kitosan dan ekstrak teh hijau yang bernilai $1,57 \times 10^{-8}-4,61$ $\times 10^{-8} \mathrm{~g} \mathrm{mmHg}^{-1} \mathrm{~m}^{-1} \mathrm{~h}^{-1}$ hasil penelitian Siripatrawan dan Harte(2010). Permeabilitas menunjukkan seberapa mudah uap air dalam menembus atau melewati film menuju produk. Semakin tinggi nilai permeabilitas uap air maka kualitas edible film dapat dikatakan semakin rendah. Rasio komponen hidrofilik-hidrofobik berperan penting dalam pembentukan matriks ikatan antar molekul. Nilai permeabilitas yang tinggi sering dijumpai pada film yang terbuat dari hidrogel atau polisakarida larut air (Alvarado-Gonzalez dkk., 2012). Penambahan bahan aktif juga akan menurunkan kerapatan molekul sehingga terbentuk ruang bebas pada matriks film yang memudahkan difusi uap air (Warkoyo dkk., 2014). Namun menurut Shabrina dkk. (2017) penggunaan lipid dan hidrokoloid dalam edible film akan menguntungkan karena lipid mampu meningkatkan ketahanan terhadap penguapan air sedangkan hidrokoloid memiliki sifat barrier yang baik terhadap oksigen dan karbondioksida.

\section{Karakteristik Kimia Edible Film}

Aktivitas antioksidan edible film meningkat seiring bertambahnya komposisi Aloe vera seperti dapat dilihat pada Gambar 4. Perbedaan terlihat dari

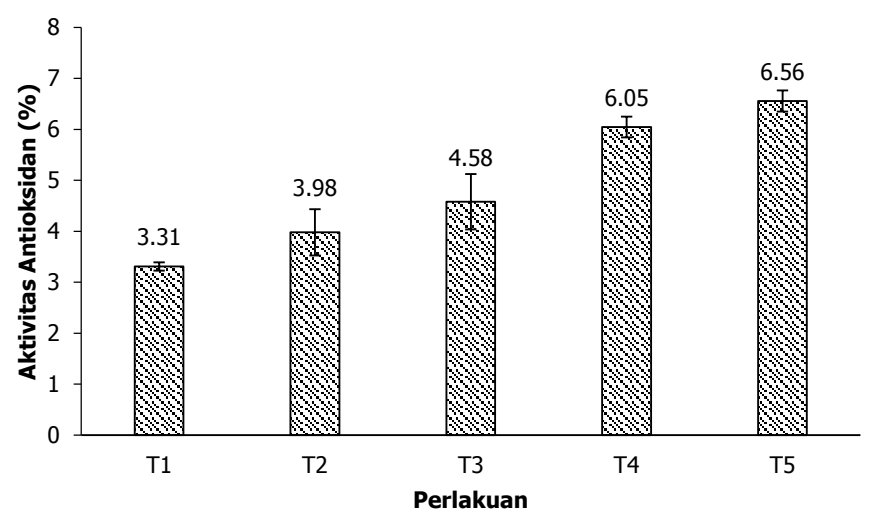

Gambar 4. Pengaruh komposisi AV dan emulsi EVOO-kitosan terhadap aktivitas antioksidan total aktivitas antioksidan yang diperoleh dari 3,31\% menjadi 6,56\% pada perlakuan T1 dan T5. Gel Aloe vera kaya akan sumber antimikroba dan antioksidan. Semakin tinggi komponen gel Aloe vera maka aktivitas antioksidan akan semakin terlihat. Adanya kitosan juga berperan baik sebagai pembawa zat fungsional seperti antimikroba dan antioksidan dalam penyalut edibel (Vieira dkk., 2016). Komponen fenolik dalam gel Aloe vera sebagai antioksidan dapat mencegah kerusakan oksidatif sehingga memperpanjang masa simpan produk (Chin dkk., 2017). Aloin dan aloe-emodin merupakan komponen fenolik dengan efek antioksidatif utama dalam gel Aloe vera selain aloesin, antrakuinon dan polisakarida.

\section{Karakteristik Mekanik Edible Film}

Berdasarkan hasil yang ditunjukkan pada Gambar 5, perlakuan komposisi menunjukkan adanya pengaruh signifikan $(p \leq 0,05)$ terhadap elongasi film. Uji lanjut Duncan menunjukkan perlakuan T1 dan T2 berbeda nyata terhadap perlakuan T3, T4, dan T5. Elongasi menunjukkan kemampuan maksimum film untuk meregang (Siriptrawan dan Harte, 2010). Semakin bertambah komposisi gel Aloe vera, nilai elongasi film akan semakin rendah. Komposisi perlakuan T1 hingga T5 menghasilkan penurunan nilai elongasi 14,72 \pm $2,92 \%$ menjadi $7,43 \pm 2,65 \%$. Hubungan antara elongasi dan tensile strength berbanding terbalik. Ikatan yang terbentuk antara kitosan dan minyak akan menghasilkan film yang bersifat plastis sehingga mampu meningkatkan nilai elongasi (Abdollahi dkk., 2012). Berkurangnya komponen emulsi dalam film dapat menyebabkan penurunan elongasi.

Hasil pengukuran tensile strength dapat dilihat pada Gambar 6.Tensile strength (TS) adalah ukuran

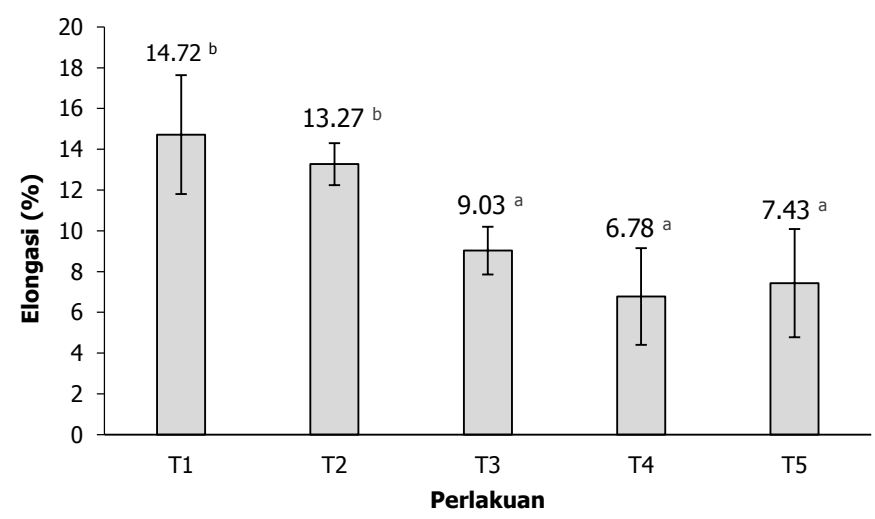

Gambar 5. Pengaruh komposisi AV dan emulsi EVOO-kitosan terhadap elongasi

Keterangan: superskrip yang berbeda menunjukkan adanya perbedaan yang signifikan $(p \leq 0,05)$ 


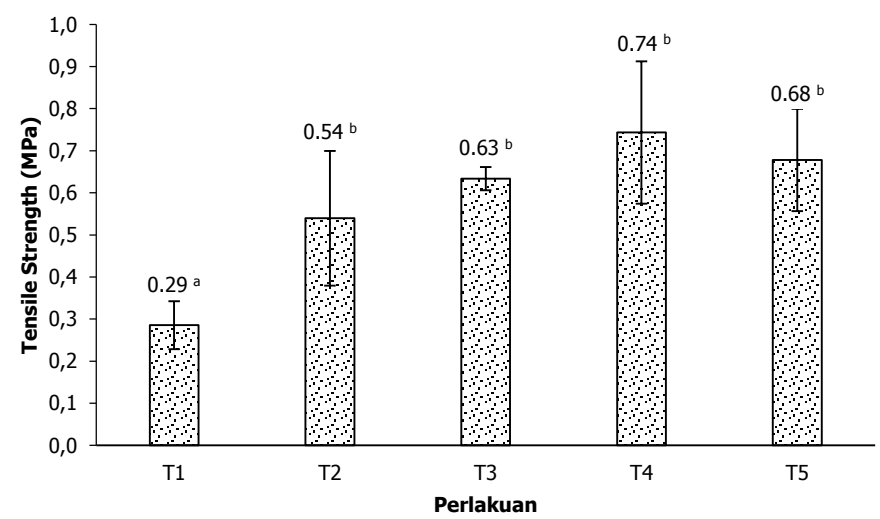

Gambar 6. Pengaruh komposisi AV dan emulsi EVOO-kitosan terhadap tensile strength

Keterangan: superskrip yang berbeda menunjukkan adanya perbedaan yang signifikan $(p \leq 0,05)$

kekuatan maksimum film dalam menahan gaya tarik (Khoshgozaran-Abras dkk., 2012). Perbedaan signifikan $(p \leq 0,05)$ antar perlakuan ditunjukkan dengan peningkatan nilai TS seiring bertambahnya persentase gel Aloe vera. Uji lanjut Duncan menunjukkan perlakuan T1 berbeda nyata terhadap perlakuan T2, T3, T4 dan T5. Nilai TS pada komposisi T1 dari 0,29 $\pm 0,06 \mathrm{MPa}$ meningkat hingga $0,68 \pm 0,12 \mathrm{MPa}$ pada komposisi T5. Hal ini menunjukkan bahwa gel Aloe vera mampu menyatu baik pada jaringan fibril sehingga mampu meningkatkan nilai TS (Saibuatong dan Phisalaphong, 2010). Jumlah gliserol yang tetap juga menghambat reduksi ikatan matriks film sehingga gaya renggang semakin kuat (Warkoyo dkk., 2014). TS tertinggi diperoleh perlakuan T4 yaitu 0,74 $\pm 0,17 \mathrm{MPa}$ dengan komposisi gel Aloe vera $55 \%$.

\section{KESIMPULAN}

Berdasarkan hasil penelitian dapat disimpulkan bahwa terdapat pengaruh signifikan antar tiap perlakuan komposisi gel Aloe vera dengan emulsi EVOO dan kitosan terhadap ketebalan, solubilitas, elongasi dan tensile strength (TS). Namun pada permeabilitas uap air, tidak terdapat perbedaan signifikan antar perlakuan. Komposisi gel Aloe vera $60 \%$ dan emulsi EVOO-kitosan $40 \%$ merupakan komposisi optimal edible film. Hal ini dikarenakan daya solubilitas, jumlah aktivitas antioksidan dan TS yang dimiliki merupakan yang tertinggi dibandingkan perlakuan lainnya. Untuk perkembangan penelitian berikutnya, dapat dilakukan perubahan rasio komposisi dan pengaplikasian film untuk mengetahui efek penggunaan film yang optimal bagi produk.

\section{DAFTAR PUSTAKA}

Abdollahi, M., Rezaei, M., \& Farzi, G. (2012). A novel active bionanocomposite film incorporating rosemary essential oil and nanoclay into chitosan. J. Food Engineering, 111(2), 343-350. doi:10.1016/j.jfoodeng.2012.02.012.

Alvarado-Gonzalez, J.S., Chanona-Perez, J.J., Welti-Chanes, J.S., Calderon-Dominguez, G., Arzate-Vazquez, I., Pacheco-Alcala, S.U., Garibay-Febles, V., \& GutierrezLopez, G.F. (2012). Optical, microstructural, functional and nanomechanical properties of Aloe vera gel/gellan gum edible films. Revista Mexicana de Ingenieria Quimica, 11(2), 193-210.

Bhattacharjee, D., \& Dhua, R.S. (2017). Impact of edible coatings on postharvest behavior of bitter gourd (Momordica charantia L.) fruits. Int. J. Curr. Microbiol. App. Sci, 6(3), 336-347. doi:10.20546/ijcmas.2017.603.038.

Casariego, A., Souza, B. W. S., Cerqueira, M. A., Teixeira, J. A., Cruz, L., Diaz, R., \& Vicente, A. A. (2009). Chitosan/ clay films' properties as affected by biopolymer and clay micro/nanoparticles' concentrations. Food Hydrocolloids, 23(7), 1895-1902. doi:10.1016/j.foodhyd.2009.02.007.

Chauhan, P., Das, A.K., Kandeepan, G., Nanda, P.K., Pradhan, S.R., Kumbhar, V., Yadav, J.P., \& Bhattacharya, D. (2016). Effect of Aloe vera gel based edible coating containing Moringa oleifera leaf extract on the quality of chicken bites. J. Food Process Technol, 7(10), 1-5. doi:10.4172/2157-7110.1000627.

Chin, S.S., Lyn, F.H., \& Hanani, Z.A.N. (2017). Effect of Aloe vera (Aloe barbadensis Miller) gel on the physical and functional properties of fish gelatin films as active packaging. Food Packaging and Shelf Life, 12, 128-134. doi:10.1016/j.fpsl.2017.04.008.

Chillo, S., Flores, S., Mastromatteo, M., Conte, A., Gerschenson, L., \& Nobile, M.A.D. (2008). Influence of glycerol and chitosan on tapioca starch-based edible film properties. J. Food Eng, 88(2), 159-168. doi:10.1016/j. jfoodeng.2008.02.002.

Diaz, L., Reales, J., \& Torres, C. (2017). Measurement of the transmittance of edible films of aloe vera (barbadensis miller) and cassava starch using optical fibers trifurcated. J. Phys.: Conf. Ser, 792, 1-5. doi:10.1088/17426596/792/1/012023.

Gunes, S., \& Tihminlioglu, F. (2017). Hypericum perforatum incorporated chitosan films as potential bioactive wound dressing material. International Journal of Biological Macromolecules, 102, 933-943.doi:10.1016/j. ijbiomac.2017.04.080.

Gutierrez, T.J., \& Alvarez, K. (2016). Physico-chemical properties and in vitro digestibility of edible films made from plantain flour with added Aloe vera gel. J. Functional Foods, 26(2), 750-762. doi:10.1016/j.jff.2016.08.054. 
Indrarti, L., \& Indriyati. (2016). Incorporation of citrus essential oils into bacterial cellulose-based edible films and assessment of their physical properties. IOP Conf. Ser: Earth and Environ. Sci, 60, 1-6. doi:10.1088/17551315/60/1/0102018

Jouki, M., Yazdi, F.T., Mortazavi, S.A., \& Koocheki, A. (2013). Physical, barrier and antioxidant properties of a novel plasticized edible film from quince seed mucilage. Int. J. Bio Macro, 62, 500-507.doi:10.1016/j. ijbiomac.2013.09.031.

Kanmani, P., Jeyaseelan, A., Kamaraj, A., Sureshbabu, M., \& Sivashanmugam, K. (2017). Environmental applications of chitosan and cellulosic biopolymers: A comprehensive outlook. Bioresource Technology, 242, 295-303. doi:10.1016/j.biortech.2017.03.119.

Khoshgozaran-Abras, S., Azizi, M.H., Hamidy, Z., \& BagheripoorFallah, N. (2012). Mechanical, physicochemical and color properties of chitosan based-films as a function of Aloe vera gel incorporation. Carbohydrate Polymers, 87, 2058-2062. doi:10.1016/j.carbpol.2011.10.020.

Ma, W., Tang, C., Yin, S., Yang, X., Wang, Q., Liu, F., \& Wei, Z. (2012). Characterization of gelatin-based edible films incorporated with olive oil. Food Research Int, 49(1), 572-579. doi:10.1016/j.foodres.2012.07.037.

Orsuwan, A., \& Sothornvit, R. (2017). Effect of banana and plasticizer types on mechanical, water barrier, and heat stability of plasticized banana-based films. J. Food Process Preservation, 41(2), 1-8. doi:10.1111/ jfpp. 13380.

Ortega-Toro, R., Collazo-Bigliardi, S., Rosello, J., Santamarina, P., \& Chiralt, A. (2017). Antifungal starch-based edible films containing Aloe vera, Food Hydrocolloids, 72, 1-10. doi:10.1016/j.foodhyd.2017.05.023.

Pereda, M., Amica, G., \& Marcovich, N.E. (2012). Development and characterization of edible chitosan/olive oil emulsion films. Carbohydrate Polymers, 87(2), 1318-1325. doi:10.1016/j.carbpol.2011.09.019.

Saibuatong, O., \& Phisalaphong, M. (2010). Novo aloe verabacterial cellulose composite film from biosynthesis. Carbohydrate Polymers, 79(2), 455-460. doi:10.1016/j. carbpol.2009.08.039.
Santoso, B., Tampubolon, O. H., Wijaya, A., \& Pambayun, R. (2014). Interaksi $\mathrm{pH}$ dan ekstrak gambir pada pembuatan edible film anti bakteri. Agritech, 34(1), 8-13. doi:10.22146/agritech.9516.

Shabrina, A. N., Abduh, S. B. M., Hintono, A., \& Pratama, Y. (2017). Sifat fisik edible film yang terbuat dari tepung pati umbi garut dan minyak sawit. JATP, 6(3), 138-142. doi:10.17728/jatp.239.

Siripatrawan, U., \& Harte, B.R. (2010). Physical properties and antioxidant activity of an active film from chitosan incorporated with green tea extract. Food Hydrocolloids, 24(8), 770-775. doi:10.1016/j.foodhyd.2010.04.003.

Soltanizadeh, N., \& Mousavinejad, M.S. (2015). The effects of Aloe vera (Aloe barbadensis) coating on the quality of shrimp during cold storage. J. Food Sci Technol, 52(10), 1-8. doi:10.1007/s13197-015-1747-x.

Talegaonkar, S., Sharma, H., Pandey, S., Mishra, P.K., \& Wimmer, R. (2017). Bionanocomposites: smart biodegradable packaging material for food preservation. In A. M. Grumezescu (Eds.), Food Packaging (pp. 79110). London, UK: Academic Press.

Thakur, R., Pristijono, P., Golding, J.B., Stathopoulos, C.E., Scarlett, C.J., Bowyer, M., Singh, S.P., \& Vuong, Q.V. (2017). Amylose-lipid complex as a measure of variations in physical, mechanical and barrier attributes of rice starch-i-carrageenan biodegradable edible film. Food Packaging and Shelf Life, 14B, 108-115. doi:10.1016/j. fpsl.2017.10.002.

Vieira, J.M., Flores-Lopez, M.L., Rodriguez, D.J., Sousa, M.C., Vicente, A.A., \& Martins, J.T. (2016). Effect of chitosan-Aloe vera coating on postharvest quality of blueberry (Vaccinium corymbosum) fruit. Postharvest Biology and Technology, 116, 88-97. doi:10.1016/j. postharvbio.2016.01.011.

Warkoyo, Rahardjo, B., Marseno, D. W., \& Karyadi, J. N. W. (2014). Sifat fisik, mekanik dan barrier edible film berbasis pati umbi kimpul (Xanthosoma sagittifolium) yang diinkorporasi dengan kalium sorbat. Agritech, 34(1), 72-81. doi:10.22146/agritech.9525. 